\title{
Comparative Analysis of the Design of an Asphalt Pavement by Rational Methodology Considering Two Different Ways of Characterizing Traffic
}

\author{
Fernando Jove Wilches ${ }^{1}$, Jorge Luis Argoty Burbano ${ }^{2}$ and Álvaro Rafael Caballero Guerrero ${ }^{3}$ \\ ${ }^{1}$ Department of Civil Engineering, Universidad de Sucre, Sincelejo, Sucre, Colombia. \\ ${ }^{2}$ Department of Civil Engineering, Universidad de Nariño, San Juan de Pasto, Nariño, Colombia. \\ ${ }^{3}$ Department of Civil and Environmental Engineering, Universidad del Norte, Barranquilla, Colombia.
}

ORCIDs: 0000-0002-2080-4036 (Fernando), 0000-0001-6661-1398 (Jorge), 0000-0002-3567-9135 (Álvaro)

\begin{abstract}
For the project of an asphalt pavement through mechanistic methods, two different ways of characterizing the traffic can be considered for design purposes: through the determination of the number of equivalent standard axles of $80 \mathrm{KN}$ expected in the design lane, or through the implementation of the load spectra, for the different configurations of axles expected during the service life. In both approaches, the aim is to determine the state of stresses to which the pavement structure will be subjected, in order to be able to determine, based on fatigue laws representative of the properties of the materials, the deterioration consumption due to fatigue of the asphalt layers and permanent deformation in the subgrade. In this work, the modeling of a proposed asphalt pavement structure for the Riohacha - Maicao road corridor has been carried out, for which the BISAR program from Shell and the TRRL fatigue laws have been used. According to the results obtained, it could be established that in cases in which the type of design traffic is characterized by a low proportion of vehicles circulating with axle loads above the legal maximum, the required design thicknesses are essentially the same for the two forms of traffic representation.
\end{abstract}

Keywords: asphalt pavement, rational design, equivalent standard axles, axle load spectra

\section{INTRODUCTION}

A pavement is a structure made up of a group of overlapping layers, relatively horizontal, which rest on the subgrade and which must adequately resist the stresses transmitted by repeated traffic loads during the period for which the structure was designed [1]. This is achieved by combining the layer thicknesses and the qualities of their constituent materials, so that they adjust to the expected conditions of traffic and environment, as well as demonstrating their economic efficiency through a cost analysis during the life cycle [2].

The design variables of a pavement can be classified into two categories: direct and indirect. Direct variables are those variables that have a "direct" impact on the thickness of the pavement layers, such as traffic, subgrade, climate, mechanical properties of materials, safety factors; and indirect ones are those that do not affect the thickness, but do, in the selection of the type of structure to be projected, such as costs, materials available in the area, topography, aesthetics, among others [3]. Among the direct variables, traffic is perhaps the most important for calculating pavement thicknesses [4], therefore, its adequate estimation is of fundamental importance in order to conceive structures that are capable of offering performance levels in accordance with the durability expected by the designer [5].

Pavement design is based on criteria that limit both horizontal and vertical deformations, which cause excessive cracking and permanent deformation. These criteria are considered in terms of repeated load applications, because the accumulated repetitions of traffic loads are of great importance in the development of cracks and in the permanent deformation of the pavement [6]. Therefore, a pavement must be designed in such a way that the loads imposed by traffic do not generate excessive permanent deformations [7].

Therefore, from the point of view of evaluating traffic for pavement design purposes, it is interesting to consider a series of factors that influence the global concept called "traffic load", among which are: the loads transmitted per wheel, the area of influence of the load, the number of repetitions of the load, the speed, the contact pressure, the number of tires per axle configuration and the axle spacing [8]. However, a good part of these factors are very difficult or impossible to reproduce in laboratories for research purposes [8], which is why, in practice, some simplifications must be used in order to be able to adequately characterize the traffic charges for design purposes.

For the purpose of structural design of a pavement, the determination of traffic requires the estimation of the number of surrounding axles through the design lane and their distribution in different load groups during the design period [2]. For this purpose, two paths are usually followed: the first, which is the one traditionally implemented by pavement engineering, consists of representing the design traffic through the quantification of the accumulated number of equivalent standard axles of 8.2 tons (ESAL) that they will circulate on the design lane during a certain design period, which depends on the category of the road [1], [9]; and the second, consists of characterizing the design transit through the so-called axle load spectra, where the vehicle load spectra are represented by the percentage of total applications of a given type of axle (simple, tandem or tridem) within a given load range [10], with which 
an estimate of the grouped effects of traffic loads [11] can be obtained.

The objective of this work was to establish a comparison between the results obtained from the structural modelling of an asphalt pavement, considering two different methodologies for the characterization of traffic loads: the first, through the number of equivalent standard axles (ESAL ); and the second, through the axle load spectra. For the modelling of the structure, a rational design methodology was used, making use of the BISAR computational tool from Shell and the fatigue laws of the Transport and Road Research Laboratory (TRRL). The information regarding traffic was obtained from a mobile weighing operation and vehicle gauging carried out within the Riohacha - Maicao road sector, located in northern Colombia

\section{METHODOLOGY}

To carry out the modeling of the pavement structure, the following considerations were taken into account:

\section{II.I Characterization of materials}

In the case of the subgrade, the resilient modulus value was estimated based on the CBR, according to the expression recommended in the Mechanistic-Empircial Pavement Design Guide, (AASHTO, 2015), which corresponds to the expression determined in the UK Road Transport and Research Laboratory (TRRL), to be applied on soils with CBR values between 2 and $12 \%$ [12]:

$M r=17.6 *(C B R)^{0.64},(M r$ in $M P a)$

For modeling purposes, a subgrade CBR value of $5 \%$ was assumed.

For the determination of the resilient modulus of the granular base and sub-base layers, these were determined as a function of their thicknesses and the resilient modulus of the support layer, according to the Shell expression [13]:

$M r_{2 i}=0.206 * h 2^{0.45} * M r 3$

Where: $\mathrm{Mr} 2 \mathrm{i}$ is the resilient modulus of the evaluated layer, $\mathrm{Mr} 3$ is the resilient modulus of the support layer, and $\mathrm{h} 2$ is the thickness of the layer, in $\mathrm{mm}$.

Regarding the Poisson ratios, the following values [13] were taken: for the asphalt layers, 0.35; for the granular base layer, 0.40 ; for the granular sub-base layer, 0.45 ; and for the subgrade, 0.50 .

\section{II.II Characterization of traffic for design}

For the characterization of the design traffic, a mobile weighing operation carried out along the Riohacha-Maicao road sector, located in northern Colombia, was taken as a reference, as well as the information related to the annual average daily traffic obtained during 2018 at the "Cuatro Vías - Maicao" toll station, run by the Instituto Nacional de Vías de Colombia (INVIAS).
To determine the total number of heavy vehicles, the following expression [1], [3] was used:

$V_{H V}=A D T_{i} \cdot \frac{A}{100} \cdot \frac{B}{100} \cdot 365 \cdot \frac{(1+r)^{n}-1}{\ln (1+r)}$

Where:

VHV: Total number of heavy vehicles in the design lane

ADTi: initial average daily traffic

A: percentage of commercial vehicles

B: factor per lane

r: annual growth rate of transit

$\mathrm{n}$ : design period (in years)

To obtain the design traffic in terms of the number of equivalent standard axles (ESAL), the value obtained in expression (3) was simply affected by the Truck Factor representative of the road corridor under study, this value representing the number of axles standard to which the passage of any commercial vehicle is equivalent [3]. For design purposes, load ranges were established for each type of axle and the number of repetitions expected for each range was determined, taking the average load in each case as a representative load. For the simple axles, a range width of one ton was taken, while for the tandem and tridem axles, two tons were taken.

\section{II.III Characterization of materials}

Based on the AASHTO-93 method for the design of flexible pavements, an initial structure was defined in order to have a starting point to carry out the modeling of the pavement structure, considering the implementation of a structure made up of an asphalt layer, a granular base. and granular sub-base. To this end, the traffic was characterized in two different ways: through the representation of equivalent standard axes and by axle load spectra. The package finally chosen was modeled by rational design methodology, considering two failure criteria: by tensile deformation in the lower fiber of the asphalt layers and by permanent vertical deformation on the subgrade. To calculate the state of stress for each type of axle and each load step, the BISAR program was used and to obtain the admissible repetitions, the fatigue laws of the TRRL (Transport and Road Research Laboratory) were taken as a reference.

\section{RESULTS}

\section{III.I Design transit evaluation}

Table 1 shows the annual average daily traffic registered during 2018 at the "Cuatro Vías - Maicao" toll station, broken down into the different typologies.

Table 2 shows the number of trucks of each type that were weighed in a mobile operation carried out along the Riohacha Maicao road corridor, which is made up of a single carriageway with two lanes and allows traffic in both directions of circulation. Likewise, the damage factors corresponding to each type of truck are presented, according to the results obtained from the heavy axles. 
International Journal of Engineering Research and Technology. ISSN 0974-3154, Volume 13, Number 10 (2020), pp. 2576-2581

(C) International Research Publication House. https://dx.doi.org/10.37624/IJERT/13.10.2020.2576-2581

Table 1. Average annual daily traffic during 2018. "Cuatro Vías - Maicao” Toll Station

\begin{tabular}{cccccccc}
\hline AVERAGE DAILY ANNUAL TRANSIT - FOUR-WAY TOLL- YEAR 2018 \\
& Cars & Buses & C2 & C3 & C3-S2 & C3-S3 & TOTAL \\
& & & & & & & \\
\hline TPDA & 4995 & 279 & 370 & 58 & 41 & 134 & 5877 \\
\hline
\end{tabular}

Source: Technical Secretariat of the National Highways Institute

Table 2. Number of heavy trucks during operation and damage factors

\begin{tabular}{ccc}
\hline $\begin{array}{c}\text { TYPE OF } \\
\text { TRUCK }\end{array}$ & NUMBER & $\begin{array}{c}\text { DAMAGE } \\
\text { FACTOR }\end{array}$ \\
\hline C2 & 879 & 2.57 \\
C3 & 57 & 3.17 \\
C3-S2 & 260 & 5.45 \\
C3-S3 & 1173 & 4.76 \\
TOTAL & 2369 & \\
\hline
\end{tabular}

From equation (3) and the information recorded in Table 1, a total volume of commercial vehicles expected in the design lane of 1,874,367 was obtained, for which a design period of 10 years was established and an annual traffic growth rate of $3.0 \%$.
By contrasting the information corresponding to the relative distribution of commercial vehicles with the damage factors shown in table 2 and assuming a damage factor for buses of 1.00, a truck factor of 2.58 was obtained; resulting in a design transit of 4,835,867 equivalent standard axles.

On the other hand, Figure 1 shows the load spectra corresponding to the four types of axles that most frequently use the country's roads: simple directional axles, simple nondirectional axles, tandem axles and tridem axles. Each figure represents the number of axles expected within a certain load range, for every 100 heavy vehicles.

In the case of buses, given that in Colombia they are not weighed during mobile weighing operations, a representative axle load of 4.75 tons was considered for the single directional axle and 7.50 tons for the single axle.

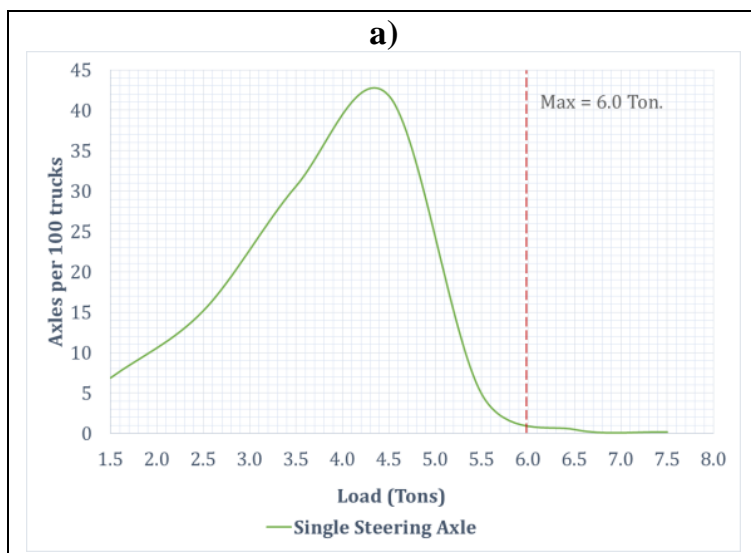

c)

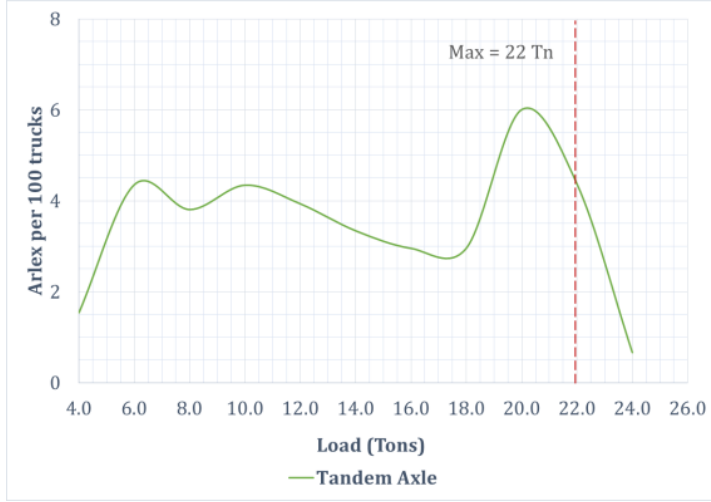

b)

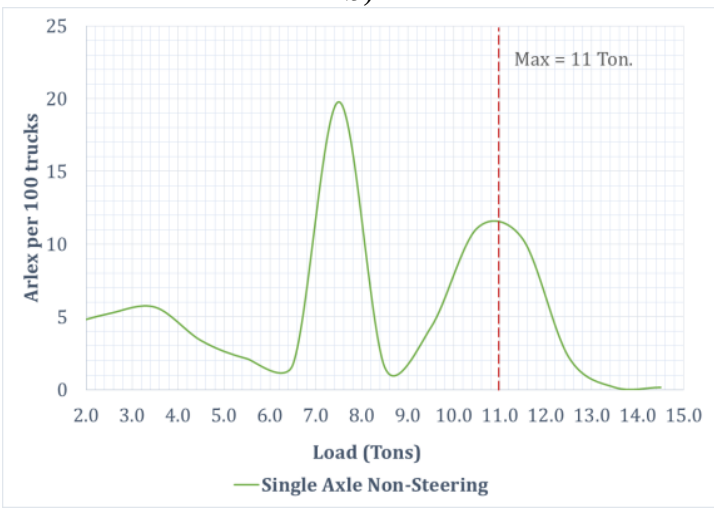

d)

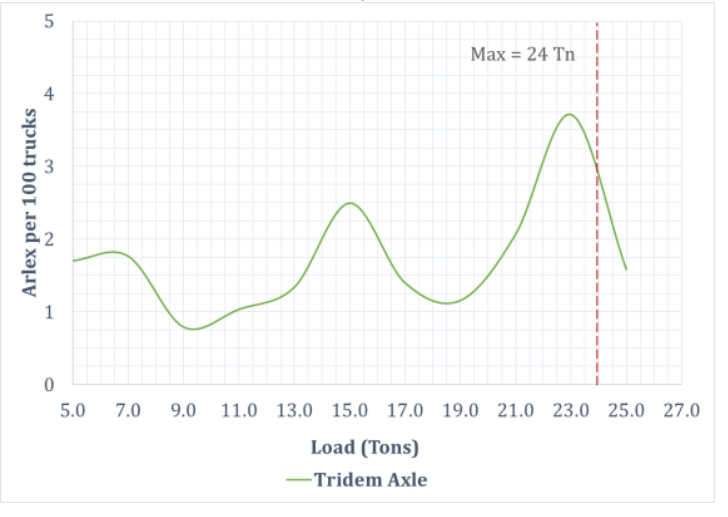

Fig. 1. Load spectrum for: a) single steering axle, b) single axle non-steering, c) Tandem Axle and d) Tridem axle 


\section{III.II Modeling the pavement structure}

After carrying out the application of the AASHTO-93 method for the design of flexible pavements and making some adjustments, the structural section of the pavement indicated in Figure 2 was established, which was modeled applying rational methodology and taking into account two different forms to represent traffic: through the number of equivalent standard axles and through axle load spectra. For the latter case, the verification was carried out considering each load step established in the load spectra, for each of the characteristics: simple directional axles, simple non-directional axles, tandem axles and tridem axles.

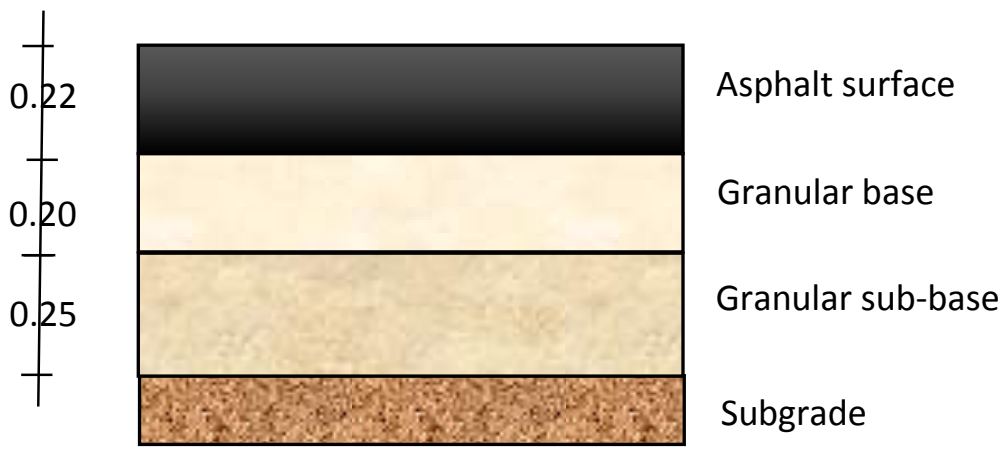

Fig. 2. Structural model for design

For the modeling of the structure, the fatigue laws of the Transport and Road Research Laboratory (TRRL) of Great Britain were used, through which the values of admissible repetitions for the two deterioration criteria considered for design purposes were obtained. : fatigue cracking in the lower fiber of the asphalt layers and permanent deformation of the subgrade. For the calculation of these parameters, equations 4 and 5 were used, respectively.

$N_{f}=f_{1} \varepsilon_{t}-f_{2}$

Where:

$\mathrm{N}_{\mathrm{f}}=$ Number of admissible repetitions, for the criterion of maximum tension deformation in the lower fiber of the asphalt layers.

$\mathrm{f}_{1}=1.66 \times 10-10$

$\mathrm{f}_{2}=4.32$
$N_{d}=f_{4} \varepsilon_{c}^{-f_{5}}$

Where:

$\mathrm{N}_{\mathrm{d}}=$ Number of admissible repetitions, for the criterion of maximum compression deformation on the subgrade.

$\mathrm{f}_{4}=6.18 \times 10-8$

$\mathrm{f}_{5}=3.97$

In Table 3, the results of the analysis performed on the pavement structure illustrated in Figure 2 are presented, for the case of the characterization of the traffic in terms of the number of equivalent standard axles. As can be seen, the fatigue damage consumption in the asphalt layers was $86.61 \%$ and the permanent deformation damage consumption on the subgrade was $43.58 \%$, with which it can be established that the proposed structure meets the two criteria of failure.

Table 3. Analysis of consumption damage due to fatigue and permanent deformation (Standard Axles)

\begin{tabular}{cclcccc}
\hline AXLE LOAD & EXPECTED & FATIGUE & ANALYSIS & \multicolumn{2}{c}{$\begin{array}{c}\text { DEFORMATION } \\
\text { ANALYSIS }\end{array}$} \\
$($ KN) & REPETITIONS & $\begin{array}{c}\text { ALLOWABLE } \\
\text { REPETITIONS }\end{array}$ & $\begin{array}{c}\text { Fatigue } \\
(\%)\end{array}$ & $\begin{array}{c}\text { ALLOWABLE } \\
\text { REPETITIONS }\end{array}$ & $\begin{array}{c}\text { Damage } \\
(\%)\end{array}$ \\
\hline 80 & $4,835,867$ & $5,583,589.82$ & 86.61 & $11,095,958.61$ & 43.58 \\
\hline
\end{tabular}

In Table 4, the results of the modelling are presented, for the case of the characterization of the traffic in terms of the expected repetitions for each load step and for each type of axle considered. According to the results obtained, it is found that the accumulated fatigue damage was $94.69 \%$ and the accumulated damage associated with permanent deformation was $34.41 \%$, which is indicative that the design obtained is optimal, fulfilling the two criteria of impairments considered in the analysis. 
International Journal of Engineering Research and Technology. ISSN 0974-3154, Volume 13, Number 10 (2020), pp. 2576-2581

(C) International Research Publication House. https://dx.doi.org/10.37624/IJERT/13.10.2020.2576-2581

Table 4. Analysis of consumption of fatigue damage and permanent deformation

\begin{tabular}{|c|c|c|c|c|c|c|}
\hline \multirow{3}{*}{ 更 } & \multirow{3}{*}{$\begin{array}{l}\text { AXLE LOAD } \\
\text { (KN) }\end{array}$} & \multirow{3}{*}{$\begin{array}{c}\text { EXPECTED } \\
\text { REPETITIONS }\end{array}$} & \multirow{3}{*}{$\begin{array}{l}\text { FATIGUE } \\
\text { ALLOWABLE } \\
\text { REPETITIONS }\end{array}$} & NALYSIS & \multicolumn{2}{|c|}{$\begin{array}{l}\text { DEFORMATION } \\
\text { ANALYSIS }\end{array}$} \\
\hline & & & & Fatigue & ALLOWABLE & Damage \\
\hline & & & & (\%) & REPETITIONS & (\%) \\
\hline \multirow{7}{*}{ 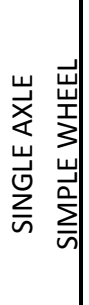 } & 15 & 251,442 & $862,788,917$ & 0.03 & $7,590,560,833$ & 0.00 \\
\hline & 25 & 410,853 & $120,309,829$ & 0.34 & $1,017,862,971$ & 0.04 \\
\hline & 35 & 828,711 & $35,099,462$ & 2.36 & $272,913,829$ & 0.30 \\
\hline & 45 & $1,131,533$ & $14,598,539$ & 7.75 & $102,390,797$ & 1.11 \\
\hline & 55 & 131,717 & $7,462,075$ & 1.77 & $46,987,760$ & 0.28 \\
\hline & 65 & 13,242 & $4,372,425$ & 0.30 & $24,647,784$ & 0.05 \\
\hline & 75 & 4,448 & $2,805,697$ & 0.16 & $14,221,669$ & 0.03 \\
\hline \multirow{14}{*}{ 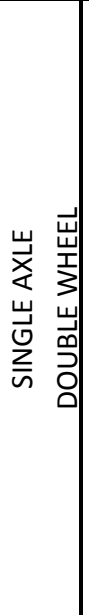 } & 15 & 118,497 & $4,384,991,541$ & 0.00 & $11,290,752,280$ & 0.00 \\
\hline & 25 & 141,538 & $532,417,333$ & 0.03 & $1,496,442,801$ & 0.01 \\
\hline & 35 & 153,411 & $136,797,278$ & 0.11 & $396,642,978$ & 0.04 \\
\hline & 45 & 91,337 & $50,587,677$ & 0.18 & $147,119,278$ & 0.06 \\
\hline & 55 & 57,548 & $23,143,206$ & 0.25 & $66,901,110$ & 0.09 \\
\hline & 65 & 47,237 & $11,816,064$ & 0.40 & $34,674,329$ & 0.14 \\
\hline & 75 & 535,163 & $6,705,548$ & 7.98 & $19,803,593$ & 2.70 \\
\hline & 85 & 41,261 & $4,096,905$ & 1.01 & $12,141,820$ & 0.34 \\
\hline & 95 & 115,797 & $2,664,933$ & 4.35 & $7,855,167$ & 1.47 \\
\hline & 105 & 299,941 & $1,814,428$ & 16.53 & $5,319,286$ & 5.64 \\
\hline & 115 & 280,048 & $1,285,329$ & 21.79 & $3,734,304$ & 7.50 \\
\hline & 125 & 60,189 & 941,203 & 6.39 & $2,701,561$ & 2.23 \\
\hline & 135 & 4,315 & 705,080 & 0.61 & $2,004,756$ & 0.22 \\
\hline & 145 & 4,315 & 539,659 & 0.80 & $1,520,454$ & 0.28 \\
\hline \multirow{11}{*}{ 崫 } & 40 & 41,653 & $1,853,086,390$ & 0.00 & $2,912,899,654$ & 0.00 \\
\hline & 60 & 117,804 & $368,665,275$ & 0.03 & $586,107,034$ & 0.02 \\
\hline & 80 & 103,004 & $112,059,028$ & 0.09 & $188,476,119$ & 0.05 \\
\hline & 100 & 117,535 & $46,777,757$ & 0.25 & $78,210,823$ & 0.15 \\
\hline & 120 & 106,424 & $21,659,044$ & 0.49 & $38,164,973$ & 0.28 \\
\hline & 140 & 90,383 & $11,391,077$ & 0.79 & $20,827,552$ & 0.43 \\
\hline & 160 & 79,924 & $6,511,446$ & 1.23 & $12,335,781$ & 0.65 \\
\hline & 180 & 80,038 & $3,968,813$ & 2.02 & $7,777,714$ & 1.03 \\
\hline & 200 & 162,488 & $2,545,492$ & 6.38 & $5,151,812$ & 3.15 \\
\hline & 220 & 118,199 & $1,701,681$ & 6.95 & $3,551,410$ & 3.33 \\
\hline & 240 & 17,902 & $1,177,353$ & 1.52 & $2,529,146$ & 0.71 \\
\hline \multirow{11}{*}{ 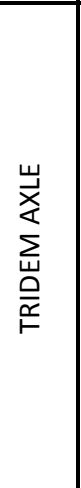 } & 50 & 46,101 & $5,601,995,403$ & 0.00 & $4,861,460,474$ & 0.00 \\
\hline & 70 & 47,747 & $1,421,853,273$ & 0.00 & $1,292,262,760$ & 0.00 \\
\hline & 90 & 21,403 & $516,788,872$ & 0.00 & $477,080,285$ & 0.00 \\
\hline & 110 & 27,990 & $233,265,512$ & 0.01 & $215,676,180$ & 0.01 \\
\hline & 130 & 36,222 & $122,096,209$ & 0.03 & $111,760,009$ & 0.03 \\
\hline & 150 & 67,504 & $70,487,012$ & 0.10 & $63,592,005$ & 0.11 \\
\hline & 170 & 37,869 & $43,926,688$ & 0.09 & $38,734,077$ & 0.10 \\
\hline & 190 & 31,283 & $29,037,241$ & 0.11 & $25,071,653$ & 0.12 \\
\hline & 210 & 55,979 & $20,151,752$ & 0.28 & $16,912,019$ & 0.33 \\
\hline & 230 & 100,433 & $13,735,024$ & 0.73 & $11,820,767$ & 0.85 \\
\hline & 250 & 42,807 & $9,658,788$ & 0.44 & $8,510,897$ & 0.50 \\
\hline & & & TOTAL: & 94.69 & TOTAL: & 34.41 \\
\hline
\end{tabular}




\section{CONCLUSIONS}

According to the results obtained, it could be observed that the critical deterioration corresponded, for both criteria, to the fatigue cracking of the asphalt layers, this consumption being slightly higher for the case of the characterization of the transit by axle load spectra $(94.69 \%$ vs. $86.61 \%)$. On the other hand, with regard to permanent deformation damage, the opposite happened, that is, the observed value was slightly higher for the case of the characterization of the traffic in terms of the number of equivalent standard axles (43.58\% vs. $34.41 \%)$.

With the results obtained, it was possible to establish that in cases in which the type of design traffic is characterized by a low proportion of vehicles circulating with axle loads above the legal maximum, the required design thicknesses are essentially the same for the two forms of representation of traffic.

\section{ACKNOWLEDGMENTS}

Author Fernando Jove, grateful the collaboration of the Technical General Secretary of INVIAS for providing information related to the vehicle weighing operation used for the development of this work.

\section{REFERENCES}

[1] Montejo A, "Ingeniería de pavimentos", 3th edition, Universidad Católica de Colombia, Bogotá, 2016.

[2] Sánchez F, Campagnoli SX, Pavimentos asfálticos de carreteras. Guía práctica para los estudios y diseños, 1 ed., Escuela Colombiana de Ingeniería, Bogotá, 2016.

[3] Rondón HA, Reyes FA, Pavimentos: Materiales, construcción y diseño, 1 ed., ECOE Ediciones, Bogotá, 2015.

[4] Reyes FA, Diseño Racional de Pavimentos, 1 ed., CEJA, Bogotá, 2003.

[5] Instituto Nacional de Vías, Manual de diseño de pavimentos asfálticos en vías con medios y altos volúmenes de tránsito. Ministerio de Transporte, Bogotá, 2015.

[6] Garber N and Hoel L, Ingeniería de tránsito y carreteras, 3 ed., Thomson editores, México, 2005.

[7] Rondón H, Reyes F, Metodologías de diseño de pavimentos flexibles: tendencias, alcances $y$ limitaciones, Ciencia e Ingeniería Neogranadina, Bogotá. 2007; 17 (2), pp. 41-65.

[8] Rico A, Del Castillo H, La ingeniería de suelos en las vías terrestres, Tomo II, editorial Limusa S.A., México, 1994.

[9] Ministerio de Transporte, Manual de Diseño de Pavimentos Asfálticos para Vías con Bajos Volúmenes de Tránsito, Instituto Nacional de Vías, Bogotá, Colombia, 2007.

[10] Macea L, Fuentes L and Marquez L, Characterization and development of closed form solutions for axle load spectra associated with trucks circulating the highways of Colombia, Revista Facultad de Ingeniería, Universidad de Antioquia. 2015; 77: pp. 32-40.

[11] Macea L and Fuentes L, Truck load spectra for the analysis and design of pavements in the Colombian, Ingeniería al Día. 2015; 1(1): pp. 24-36.

[12] Ministerio de Transporte, Manual de Diseño de Pavimentos Asfálticos en Vías con Medios y Altos Volúmenes de Tránsito, Instituto Nacional de Vías, Bogotá, Colombia, 2015.

[13] Ministerio de Transporte, Guía metodológica para el diseño de obras de rehabilitación de pavimentos asfálticos de carreteras, segunda edición, Instituto Nacional de Vías, Bogotá, Colombia, 2008. 